\title{
Kjemisk klima og helseproblemer
}

\author{
J. Låg \\ Norges landbrukshøgskole, 1432 As \\ Telefon 64948265 Telefax 64948211
}

\begin{abstract}
SAMMENDRAG
Fysiske klimafaktorer har alltid vært fulgt med oppmerksomhet fra menneskene, mens interessen for kjemisk klima er av nyere dato. Viktige årsaker til den nye interessen er at naturforurensning tillegges større betydning enn før, og at det $\mathrm{i}$ vår tid er et utbredt ønske om sterkere innsats $\mathrm{i}$ forebyggende helsearbeid. Det er påvist at i humusdekket i naturlig jordsmonn avtar innholdet av hovedbestandeler som natrium og magnesium stort sett med stigende avstand fra havet. Lignende lovmessigheter gjelder også for sporstoffer som jod, brom, klor og selen. I tillegg avtar disse også med nedbørsmengden. Dette tyder på at tilførsel av marine elementer til jordsmonn via nedbør er en meget viktig geokjemisk prosess, og de kan ha stor betydning for menneskers og dyrs helse. Endringer i nedbørens surhetsgrad og variasjoner i mengdeforholdet mellom de stoffer som tilføres jordsmonnet kan gi betydelige utslag i flora og fauna. Store befolkningsgrupper påvirkes til enhver tid av viktige kjemiske klimafaktorer, og det er sterkt ønskelig at forskning og veiledning innenfor dette fagfeltet intensiveres.
\end{abstract}

Låg J. Chemical climate and health problems. Nor J Epidemiol 1998; 8 (1): 19-20.

\section{ENGLISH SUMMARY}

Physical factors of the climate have for a long time been considered to be of great interest. Variations in the chemical climate have received a growing attention only in the period after World War II, a trend which is due to an increasing interest in pollution and preventive health activities in our times. The contents of some of the major constituents in surface soil, such as sodium and magnesium, have been found to decrease with increasing distance from the sea. The contents of trace elements, such as iodine, bromine, chlorine, and selenium also show this type of distributional patterns, but in addition the contents in the soil of these elements increase with the amount of precipitation. Such data indicate that airborne transportation of elements from the sea to the continents is a geochemical process of great importance for most types of biological life. Great population groups are to a varying degree influenced by factors of the chemical climate, and increased research activities in this field is desirable.

\section{INNLEDNING}

Mange miljøfaktorer blir behandlet under betegnelsen klima. Gjennom lang tid er fysiske faktorer som temperatur, nedbør, vind, lufttrykk, m.v. blitt registrert. I tilknytning til utredning av lovmessigheter for planteproduksjon ble det tidlig utført bestemmelser av innholdet av karbondioksid i atmosfæren og av mengder av nitrogenforbindelser som tilføres jordoverflaten. Men generelt sett var interessen for kjemiske klimafaktorer lenge relativt liten. Svakheter i kjemisk analysemetodikk var en medvirkende årsak til dette.

Jodmangel som mulig årsak til struma ble tatt opp til diskusjon av blant andre Goldschmidt (1954), som framhevet at transport av jod fra havvann gjennom atmosfæren til jordsmonn var en meget viktig prosess. Låg påviste i 1962 at under norske forhold avtar innholdet av ombyttbart natrium og magnesium i humusdekket med stigende avstand fra havet. Senere ble det funnet lignende fordelingsmønster for elementene jod, brom, klor og selen og at jordsmonnets innhold av disse sporstoffene øker med økende nedbørsmengder. Begrepene kjemisk klima og kjemisk klimatologi ble innført (Låg 1990, 1992).

I faget geomedisin behandles innvirkninger av alminnelige ytre miljøfaktorer på geografisk fordeling av helseproblemer hos mennesker og dyr. Norge har store naturvariasjoner innenfor forholdsvis små områder. Vårt land skulle derfor ha gode naturlige vilkår for utredning av en del geomedisinske spørsmål. Kjemisk klima representerer en interessant gruppe faktorer i denne sammenheng.

Det ville være ønskelig å kunne tallfeste de helseproblemer som skyldes kjemisk klima. Foreløpig har vi for mangelfulle kunnskaper for å gjøre dette på en uttømmende måte, men noen eksempler på konsekvenser av utilstrekkelig tilførsel av grunnstoffer via nedbør kan nevnes. 


\section{JOD- OG SELENMANGEL}

I 1960 ble det publisert resultater av en omfattende undersøkelse som indikerte at nær 200 millioner mennesker på det tidspunktet var plaget av endemisk struma (Kelly \& Snedden 1960). Gjennom lang tid hadde det da vært kjent at jodtilførsel kunne hjelpe mot denne sykdommen, men dette mottiltaket må altså ha vært anvendt i for lite omfang.

I ca. 40 år har det vært kjent at selen er et nødvendig næringsstoff for dyr (Schwarz \& Foltz 1957). Kort tid etter denne oppdagelsen ble det i mange land sørget for innblanding av selenforbindelser i kraftfôr til husdyr, i noen land også tilsetning av selen til handelsgjødsel. Selenholdige tabletter for mennesker kom $i$ handelen. Det er ikke påvist at selen er nødvendig for planter.

Eksakte oppgaver over hvor mange mennesker på jorden som er utsatt for selenmangel finnes ikke. Men det regnes med at antallet kan være meget stort. Således er den såkalte Keshan-sykdommen og lignende lidelser utbredt i visse regioner i Kina. Slike sykdommer kan forebygges ved bruk av selenpreparater.

Muskeldystrofi hos husdyr var en alvorlig sykdom i Norge før seleninnblanding i fôret ble gjennomført. Denne lidelsen hadde vært særlig alminnelig hos sau i de nordlige delene av Gudbrandsdalen og Østerdalen, altså i nedbørfattige områder i stor avstand fra havet.

På syttitallet ble det fremmet hypoteser om at noen former for hjertelidelser kan skyldes magnesiummangel (Angino et al. 1979). Det ble også påpekt at høye K:Na-forhold i føden kan være gunstige når det gjelder å unngå enkelte typer av kreft (Jansson 1991). Hos husdyr kan såkalt graskrampe forekomme når magnesiuminnholdet i beiteplantene er særlig lavt.

På øya Smøla er klimaet ekstremt oseanisk. I gjødslingsforsøk er det her påvist at det er for lite av de fleste plantenæringsstoffene. Et unntak er magnesium. Dette grunnstoffet tilføres sannsynligvis i rikelige mengder gjennom nedbør.

Industrialisering har forårsaket forurensning av atmosfære, vann og jord. Økt tilførsel av sur nedbør kan føre til at elementer som molybden og selen blir vanskeligere tilgjengelige for planter, mens elementer som mangan, bor, kobber og sink blir lettere tilgjengelige. Uønskede elementer som bly, kadmium, kvikksølv og arsen kan opphopes i jordsmonnet og få meget langvarige virkninger.

Plantenes muligheter for opptak av et gitt grunnstoff er i mange tilfeller også avhengig av innholdet av andre grunnstoffer. Et typisk eksempel er innvirkning på mangelsituasjoner/giftvirkninger av henholdsvis kobber og molybden der mengdeforhold mellom de to stoffene kan være avgjørende. Andre lignende samspill mellom grunnstoffer er kjent, og flere vil sannsynligvis bli avdekket ved framtidig forskning. Undersøkelser av forurensninger i atmosfæren kan føre til oppdagelse av forhold og reaksjoner som tidligere var ukjente.

\section{KONKLUSJON}

I seinere år har det foregått en meget rask utvikling med hensyn til muligheter for karakterisering av kjemiske klimafaktorer. Noen helseproblemer av geomedisinsk interesse er etter hvert blitt klarere beskrevet enn før. Det skulle nå være sjanser for å finne løsninger på mange alvorlige geomedisinske problemer.

Muligheter for internasjonalt samarbeid om slike spørsmål bør utredes. Det kan tenkes at verdensomfattende organisasjoner i geologi, jordbunnslære, klimatologi, landbruk og helsestell vil delta i slikt samarbeid i større grad enn nå. I 1986 opprettet Det internasjonale selskapet for jordbunnslære en arbeidsgruppe som ble kalt «Soils and Geomedicine».

I noen tilfeller er det tenkelig at utgifter kan reduseres ved sammenkobling til undersøkelser som er i gang for andre formål. F.eks. inngår analysering av blod og urin i mange forskjellige undersøkelser.

Et meget stort antall mennesker har føling med problemer som kjemisk klima er årsak til. Utvidet forsknings- og rettledningsinnsats i dette fagfeltet er sterkt ønskelig.

\section{REFERANSER}

Angino EE, et al. (Panel on the geochemistry of water in relation to cardiovascular disease). Geochemistry of water in relation to cardiovascular disease. Washington, D.C.: American Geological Institute, 1979, 98 pp.

Goldschmidt VM. Geochemistry. Oxford: Clarendon Press, 1954, 608 pp.

Jansson B. Studies on the relationship between selenium and cancer incidence. I: Låg J, red. Human and animal health in relation to circulation processes of selenium and cadmium. Oslo: Norwegian Academy of Science and Letters, 1991: 47-54.

Kelly FC, Snedden WW. Prevalence and geographical distribution of endemic goitre. World Health Organization, Monograph Series, 1960; 44: 27-233.

Låg J, red. Geomedicine. Boca Raton: CRC Press, 1990, 278 pp.

Låg J, red. Chemical climatology and geomedical problems. Oslo: The Norwegian Academy of Science and Letters, 1992, $253 \mathrm{pp}$.

Schwarz K, Foltz CM. Selenium as an integral part of factor 3 against dietary necrotic liver degeneration. $J$ Am Chem Soc 1957; 79: 3292-3293. 